\title{
Perbedaan Kemandirian Berdasarkan Tipe Pola Asuh Orang Tua pada Siswa SMP Negeri di Denpasar
}

\author{
Ayu Winda Utami Santosa dan Adijanti Marheni \\ Program Studi Psikologi, Fakultas Kedokteran, Universitas Udayana \\ aw.ayuwinda@gmail.com
}

\begin{abstract}
Abstrak
Dalam proses tumbuh kembang, seorang anak mulai terbentuk kepribadiannya oleh keluarga. Orangtua merupakan lingkungan pertama yang paling berperan dalam gaya pengasuhan anaknya, sehingga mempunyai pengaruh yang paling besar terhadap pembentukan kemandirian. Pola asuh merupakan salah satu faktor yang sering disebut penyebab bagi perkembangan kemandirian. Setiap orangtua memiliki cara pengasuhan yang berbeda-beda maka dari itu akan menghasilkan kemandirian anak yang berbeda pula. Penelitian ini bertujuan untuk mengetahui perbedaan kemandirian berdasarkan tipe pola asuh orangtua pada siswa SMP Negeri di Denpasar.

Penelitian ini adalah penelitian kuantitatif komparasi. Subjek penelitian ini adalah Siswa kelas VII SMP Negeri di Denpasar sebanyak 360 orang. Metode pengambilan sampel dengan metode Proportionate Stratified Random Sampling. Metode pengambilan datanya dengan menggunakan Skala Pola Asuh yang telah diuji validitasnya, dengan reliabilitas 0,886 demikian juga Skala Kemandirian juga memiliki reliabilitas 0,876. Sebaran data yang diperoleh menunjukan data normal dan homogen. Metode analisis statistik dengan teknik komparasi One Way Anova. Didapatkan hasil F= 9,998; $\mathrm{p}=0,000$ dan analisis Post Hoc mendapatkan hasil yang menunjukkan bahwa Pola asuh Autoritatif dengan Otoriter memiliki signifikansi sebesar 0,000, pola asuh Autoritatif dengan Permisif sebesar 0,023, pola asuh Permisif dengan Otoriter sebesar 0,002. Artinya adanya perbedaan kemandirian berdasarkan tipe pola asuh Autoritatif dengan Otoriter, perbedaan kemandirian pola asuh Autoritatif dengan Permisif, dan ada perbedaan kemandirian pada pola asuh Permisif dengan Otoriter pada siswa SMP Negeri di Denpasar. Pola asuh Autoritatif merupakan tipe pola asuh orangtua yang memiliki anak dengan kemandirian paling baik.
\end{abstract}

Kata kunci : pola asuh orangtua, kemandirian, siswa SMP

\begin{abstract}
In the developmental process, a child begins to form his personality through the family. The first environment that have most responsible on parenting children is the parents, then it has main influence on establishment of selfautonomy. The parenting style is one of the factor that frequently mentioned as cause for the development of selfautonomy. Every parent using different parenting style, therefore it will obtain different self-autonomy on every child also. The aim of this research is to investigate the difference of self-autonomy based on parenting style of the junior high school students in Denpasar.

This research is a quantitative comparisons research. The subject of this research were 360 VII grade students of Junior High School in Denpasar. The sample were selected using proportionate stratified random sampling method. The data was collected through scales of parenting style that have been tested with reliability 0,886 and scales of selfautonomy that have been tested with reliability 0,876 . Distribution of data obtained showed normal data and homogeneous data. Data obtained in this research is processed by comparisons of one way anova technique. Obtained results $F=9,998 ; p=0.000$ and Post Hoc analysis results showed that the Authoritative Parenting with Authoritarian Parenting have significance of 0.000 , Authoritative Parenting and Permissive Parenting of 0,023, Permissive parenting with Authoritarian parenting of 0.002. The result indicate that there are significant differences between selfautonomy based on the type of Authoritative Parenting with Authoritarian Parenting, self-autonomy based on the type of Authoritative Parenting with Permissive parenting, and self-autonomy based on the type of Permissive Parenting and Authoritarian Parenting on Junior High School Students in Denpasar. Authoritative parenting is the type of parenting that obtain children with the best self autonomy.
\end{abstract}

Keywords : parenting style, self-autonomy, junior high school students 


\section{LATAR BELAKANG}

Dewasa ini masih terdapat remaja khususnya remaja awal yang masih bergantung pada orang lain terutama pada orangtua. Lie \& Prasasti (2004) menyatakan bahwa remaja awal berada pada rentangan usia 12-15 tahun, dimana pada masa ini remaja awal sedang mengembangkan jati diri dan melalui proses pencarian identitas diri. Sehubungan dengan itu pula rasa tanggungjawab dan kemandirian mengalami proses pertumbuhan, masa remaja ini merupakan masa peralihan dimana anak mulai meninggalkan masa kanak-kanak mereka dan memasuki masa remaja awal.

Bentuk ketergantungan remaja pada orang lain mengakibatkan tidak adanya rasa tanggungjawab pada masing-masing indvidu, sehingga remaja memiliki sikap yang tidak mandiri. Salah satu contoh bentuk ketergantungan remaja yang dipaparkan pada artikel online Balipost, BP (2009) dimana pada kasus tersebut seorang anak siswa SMP kelas 1 sulit dalam berkonsentrasi dan sering melakukan kesalahan yang terus berulang saat melakukan sesuatu untuk dirinya sendiri, salah satu contohnya beberapa kali siswa tidak membawa kembali baju olahraga. Dia juga kerap lupa membawa kembali tas berenang dan sudah terjadi puluhan kali. Pada umumnya kejadian tersebut disebabkan beberapa faktor. Antara lain karena banyaknya pembantu di rumah yang menghambat kemandirian anak sehingga segalanya telah dipersiapkan, gaya pengasuhan yang permisif, dan stres yang disebabkan emosi negatif sehingga membuat anak tidak konsentrasi. Dikaitkan dengan pernyataan menurut Mutadin (2002) yang menyatakan bahwa kemandirian pada anak berawal dari keluarga serta dipengaruhi oleh pola asuh orangtua. Pada masa peralihan ini orangtua seharusnya menerapkan pola asuh yang tepat agar dapat mendidik anaknya untuk menjadi pribadi yang mandiri untuk kedepannya. Pada mulanya seorang anak akan bergantung kepada orang-orang di sekitarnya terutama orangtua hingga waktu tertentu. Kemudian secara perlahan-lahan anak melepaskan ketergantungan sehingga tercapailah kemandirian. Tercapainya kemandirian akan menjadikan seseorang tidak bergantung pada orang-orang di sekitarnya, seorang anak akan mampu untuk mengatur dirinya sendiri dalam bertanggung jawab, mengambil keputusan secara mandiri, juga mampu memaknai seperangkat prinsip-prinsip nilai.

Permasalahan kemandirian lain juga dipaparkan oleh Bisono (dalam BNN, 2011) yaitu gagalnya kemandirian remaja sebagai penyebab utama meningkatnya penyalahgunaan narkotika, minuman keras, ekstasi dan obatobatan terlarang. Dalam hal ini remaja dalam konteks sosiabilitas yang sangat luas, dunia remaja memang dunia yang penuh gejolak, kecemasan, kebingungan, yang justru merupakan suatu proses terpenting dalam tahap pendewasaan seorang remaja. Namun sebagai remaja, keterkaitan yang kuat justru harus tercipta dari hubungan remaja dengan orangtua. Hubungan tersebut yang diharapkan dalam kondisi sehat, terbuka, dan positif, sehingga dapat berfungsi sebagai tameng terhadap berbagai pengaruh negatif yang ada didalam masyarakat. Banyak orangtua yang masih menganggap bahwa remaja mereka itu masih merupakan anak kecil, sehingga masih terus harus dituntun. Padahal mereka sudah memiliki kemampuan, walaupun masih dalam taraf belajar untuk bersikap mandiri, melakukan pilihan dan memutuskan apa yang terbaik bagi mereka. Jika dikaitkan dengan permasalahan perkembangan yaitu kemandirian, pada kasus tersebut dipaparkan bahwa problema kaum muda tidak dapat diisolir sebagai problema mereka sendiri karena itu tidak juga salah bila kita mulai melihat persoalan kenakalan remaja secara bersamaan dengan masalah kenakalan orang tua. Salah satu contohnya bila para remaja sering dikritik karena terlalu banyak membuang-buang waktu untuk hal-hal yang tidak bermanfaat sehingga prestasi belajarnya menurun, maka kritik juga dapat disampaikan kepada para orangtua yang terlalu banyak membuang-buang waktu untuk mengejar prestasi karier, sehingga hampir tidak ada waktu untuk berdiskusi dengan menempatkan problema remaja dengan orangtua, hal ini sebagai bagian dari problema masyarakat secara keseluruhan. Padahal kita tahu bahwa pada tingkat usia remaja inilah perkembangan psiko-sosial membutuhkan kepekaan ekstra dari orangtua dan lingkungan masyarakat. Dapat diihat pada pernyataan Hurlock didukung oleh pendapat Mutadin (2002) yang menjelaskan bahwa selama masa remaja tuntutan terhadap kemandirian sangat besar dan jika tidak direspon secara tepat bisa saja menimbulkan dampak yang tidak menguntungkan bagi perkembangan psikologis sang remaja di masa mendatang. Rice (dalam Aspin, 2006) mengemukakan pencapaian tingkat kemandirian bagi remaja merupakan suatu hal yang tidak mudah, karena pada masa remaja ini terjadi pergerakan psikososial dari arah lingkungan keluarga menuju lingkungan luar keluarga. Seorang remaja berusaha dalam melakukan pelepasan yang selama ini dialami pada masa kanak-kanak dengan segala sesuatunya yang serba diatur dan ditentukan oleh orangtua.

Bertitik tolak dari hal tersebut, perlunya menanamkan sikap kemandirian kepada remaja khusunya remaja awal, agar remaja awal lebih bertanggungjawab pada dirinya sendiri. Selain itu terdapat beberapa dampak positif yang diperoleh dari kemandirian, antara lain remaja akan mampu menyesuaikan diri dengan keadaan lingkungan dan dapat mengatasi kesulitan yang terjadi. Di samping itu remaja yang memiliki kemandirian akan memiliki stabilitas emosional dan ketahanan yang mantap dalam menghadapi tantangan dan tekanan.

Siswoyo (2007) mendefinisikan kemandirian sebagai suatu karakteristik individu yang mengaktualisasikan dirinya, menjadi dirinya seoptimal mungkin, dan ketergantungan pada 
tingkat yang relatif kecil. Orang-orang yang demikian relatif bebas dari lingkungan fisik dan sosialnya. Meskipun mereka tergantung pada lingkungan untuk memuaskan kebutuhan dasar, sekali kebutuhan terpenuhi mereka bebas untuk melakukan caranya sendiri dan mengembangkan potensinya.

Menurut Steinberg (2002) kemandirian merupakan kemampuan dalam mengatur perilaku sendiri untuk memilih dan memutuskan keputusan sendiri serta mampu mempertanggungjawabakan tingkah lakunya sendiri tanpa terlalu tergantung pada orangtua. Steinberg (2002) juga mengungkapkan tentang kemandirian remaja adalah kemampuan remaja untuk mencapai sesuatu yang diinginkannya setelah remaja mengaksplorasi sekelilingnya. Hal ini mendorong remaja untuk tidak tergantung kepada orangtua secara emosi dan mengalihkannya pada teman sebaya, mampu membuat keputusan, bertanggungjawab dan tidak mudah dipengaruhi orang lain.

Marheni (dalam Soetjiningsih, 2004) pada awal usia remaja, perjuangan kemandirian ditandai dengan perubahan dari sifat tergantung kepada orangtua menjadi tidak tergantung. Pada saat ini remaja sudah tidak tertarik lagi dengan aktifitas bersama orangtua, tidak mau mendengar nasihat atau kritik dari orangtua, ikatan emosional dengan orangtua menjadi berkurang.

Perkembangan kemandirian seorang remaja, tidak terlepas dari penerapan gaya pengasuhan orangtua melalui interaksi antara ibu dan ayah dengan anaknya. Orangtua merupakan lingkungan pertama yang paling berperan dalam gaya pengasuhan anaknya, sehingga mempunyai pengaruh yang paling besar terhadap pembentukan kemandirian. Seorang anak akan tumbuh menjadi seorang remaja mandiri yang memiliki emosi baik dalam berbuat, maupun berprinsip, dalam hal tersebut sangat dipengaruhi oleh gaya pengasuhan orangtua di dalam lingkungan keluarganya (Erikson dalam Monks, 1999).

Ali dan Asrori (2004) menyatakan pola asuh sebagai salah satu faktor yang sering disebut penyebab bagi perkembangan kemandirian. Penyebab yang dimaksud meliputi gen atau keturunan orangtua, pola asuh orangtua, sistem pendidikan di sekolah, dan sistem kehiduan dimasyarakat. Orangtua memiliki peranan penting dalam mengasuh, membimbing dan mengarahkan anak untuk menjadi lebih mandiri. Adapun beberapa tipe pola asuh orangtua dalam menerapkan gaya pengasuhan pada remaja awal. Dengan adanya berbagai tipe tersebut kepribadian remaja dibentuk sesuai dengan gaya pengasuhan yang diberikan pada masing-masing orangtua, maka dari itu setiap remaja memiliki karakteristik yang berbeda.

Pola asuh orangtua merupakan segala bentuk dan proses interaksi yang terjadi antara orangtua dan anak yang merupakan pola pengasuhan tertentu dalam keluarga yang akan memberi pengaruh terhadap perkembangan kepribadian anak (Baumrind dalam Irmawati, 2002). Baumrind (1991) juga mengungkapkan pendapat tentang pola asuh bahwa para orangtua tidak boleh menghukum dan mengucilkan anak, tetapi sebagai gantinya orangtua harus mengembangkan aturan-aturan bagi anak dan mencurahkan kasih sayang kepada mereka. Orangtua juga perlu untuk melakukan penyesuaian perilaku mereka terhadap anak, yang didasarkan atas kedewasaan perkembangan anak karena setiap anak memiliki kebutuhan dan mempunyai kemampuan yang berbeda-beda.

Tipe-tipe pola asuh orangtua menurut Baumrind (2002), yaitu pola asuh autoritatif, pola asuh otoriter, dan pola asuh permisif. Pola asuh autoritatif ditandai dengan sikap terbuka antara orangtua dengan anaknya, menghargai otonomi maupun perilaku disiplin. Pola asuh autoritatif, akan mendorong anak untuk mampu berdiri sendiri, bertanggung jawab dan yakin terhadap diri sendiri. Pola asuh otoriter ditandai dengan adanya aturan-aturan yang kaku dari orangtua, cenderung untuk menentukan peraturan tanpa berdiskusi dengan anak-anak mereka terlebih dahulu. Dalam hal ini pola asuh otoriter dapat berdampak buruk pada anak, yaitu anak merasa tidak bahagia, ketakutan, tidak terlatih untuk berinisiatif (kurang berinisiatif), selalu tegang, cenderung ragu, tidak mampu menyelesaikan masalah, kemampuan komunikasinya buruk serta mudah gugup. Pola asuh permisif ditandai dengan adanya kebebasan tanpa batas pada anaknya untuk berperilaku sesuai dengan keinginannya sendiri. Seorang anak tidak tahu apakah perilakunya benar atau salah karena orangtua tidak pernah membenarkan atau menyalahkan anak. Akibatnya anak akan berperilaku sesuai dengan keinginannya sendiri, tidak peduli apakah hal itu sesuai dengan norma masyarakat atau tidak. Namun bila anak mampu menggunakan kebebasan tersebut secara bertanggung jawab, maka anak akan menjadi seorang yang mandiri, kreatif, inisiatif, dan mampu mewujudkan aktualisasinya

Berdasarkan data-data tentang kemandirian dan pola asuh orangtua pada remaja yang telah dipaparkan di atas, peneliti tertarik untuk melihat lebih lanjut mengenai tingkat kemandirian pada masing-masing tipe pola asuh orangtua. Oleh karena itu, pada penelitian ini, peneliti tertarik untuk melihat perbedaan kemandirian berdasarkan tipe pola asuh orangtua pada siswa SMP Negeri di Denpasar.

\section{METODE}

\section{Variabel dan definisi operasional}

Variabel penelitian secara teoritis didefinisikan sebagai atribut seseorang atau objek yang mempunyai "variasi" antara satu orang dengan yang lain dan ditetapkan oleh peneliti utnuk dipelajari sehingga diperoleh informasi 
tentang hal tersebut, kemudian dapat ditarik kesimpulannya (Sugiyono, 2012). Variabel bebas merupakan variabel yang mempengaruhi atau yang menjadi sebab perubahannya atau timbulnya variabel dependen (terikat). Variabel tergantung merupakan variabel yang dipengaruhi atau yang menjadi akibat, karena adanya variabel bebas (Sugiyono, 2012). Dalam penelitian ini, variabel bebas yang digunakan adalah pola asuh orangtua, sedangkan variabel tergantungnya adalah kemandirian.

Definisi operasional dari pola asuh orangtua adalah kemampuan orangtua dalam menyediakan waktu untuk mengasuh, membimbing, serta mengarahkan anaknya menjadi lebih baik. Dari cara perlakuan orangtua akan mencerminkan karakteristik tersendiri yang mempengaruhi pola sikap anak kemudian hari. Gambaran pola asuh orangtua yang ditujukan pada siswa SMP ini diukur melalui skala pola asuh orangtua yang terdiri dari tipe pola asuh autoritatif, tipe pola asuh otoriter, dan tipe pola asuh permisif. Variabel pola asuh ini diukur dengan menggunakan kuisioner yang telah dimodifikasi oleh peneliti dari skala Fakhriyani (2011) berlandaskan teori Baumrind (1991) agar sesuai dengan tujuan penelitian dengan model skala likert.

Definisi operasional dari kemandirian adalah suatu sikap individu yang mampu berdiri sendiri tanpa terlalu bergantung pada orang-orang disekitarnya terutama pada orangtua serta mampu dalam memilih dan menentukan pilihan sendiri sesuai yang diinginkannya. Tingkat kemandirian dapat diukur melalui skala kemandirian yang terdiri dari dimensi kemandirian, yaitu kemandirian emosi, kemandirian perilaku, dan kemandirian nilai. Variabel Kemandirian diukur dengan menggunakan kuisioner yang telah dimodifikasi oleh peneliti dari skala Imtiyas (2010) berlandaskan teori Steinberg (2002) agar sesuai dengan tujuan penelitian dengan model skala likert.

\section{Responden}

Populasi adalah wilayah generalisasi yang terdiri atas : obyek atau subyek yang mempunyai kualitas dan karakteristik tertentu yang ditetapkan oleh peneliti untuk dipelajari dan kemudian ditarik kesimpulannya (Sugiyono, 2012). Sampel adalah bagian dari jumlah dan karakteristik yang dimiliki oleh populasi (Sugiyono, 2012). Dalam penelitian ini populasi yang diambil adalah siswa SMP Negeri di Denpasar. Subjek dalam penelitian ini siswa kelas VII yang masih memiliki orangtua lengkap, tinggal bersama orangtuanya, dan siswa yang bersekolah di SMP Negeri di Denpasar.

Peneliti menggunakan metode probabilitas sampling yaitu Propotionated Stratified Random Sampling merupakan teknik pengambilan sampel populasi yang mempunyai anggota yang berstrata secara proporsional dari setiap elemen populasi yang dijadikan sampel dan pengambilan sampel dilakukan secara random (Sugiyono, 2012). Pada penelitian ini, peneliti menetukan sampel daerah. Dimana pada penelitian ini Kota Denpasar yang memiliki 4 Kecamatan, pada masingmasing kecamatan diambil 1 sekolah SMP Negeri di Denpasar sesuai dengan kecamatan secara random, kemudian mengambil sampel yang sesuai dengan kriteria inklusi pada masing-masing sekolah yang sudah dipilih secara random untuk digunakan sebagai subjek penelitian.

\section{Tempat penelitian}

Penelitian dilakukan di Kota Denpasar, dengan mengambil populasi siswa SMP Negeri di Denpasar. Subjek dalam penelitian ini adalah siswa kelas VII yang masih memiliki orangtua lengkap, tinggal bersama orangtuanya, dan siswa yang bersekolah di SMP Negeri di Denpasar.

Pengambilan sampel penelitian dilakukan selama bulan Desember tahun 2012 sampai dengan bulan Maret tahun 2013. Sebelum melakukan penelitian, peneliti melakukan try out dengan mengambil 65 responden yang merupakan siswa kelas VII SMP Negeri di Denpasar.

\section{Alat ukur}

Dalam penelitian ini skala yang digunakan ada dua yaitu, skala pola asuh orangtua, skala kemandirian yang telah dimodifikasi oleh peneliti sesuai dengan karakteristik subjek penelitian.. Skala pola asuh orangtua disusun berdasarkan tipe pola asuh orangtua menurut Baumrind (dalam Fakhriyani, 2011) bahwa terdapat tiga tipe pola asuh orangtua, yaitu pola asuh autoritatif, pola asuh otoriter, dan pola asuh permisif. Skala kemandirian disusun berdasarkan dimensi kemandirian dari Steinberg (dalam Imtiyas, 2010) yaitu kemandirian emosi, kemadnirian perilaku, dan kemandirian nilai.

Sebelum alat ukur digunakan dalam melakukan penelitian dilaksanakan uji coba terlebih dahulu terhadap kuesioner. Instrumen dinyatakan valid dengan melihat hasil koefisien korelasi item total sebesar 0,20 (Nurgiyantoro, Gunawan, \& Marzuki, 2009). Uji coba yang dilakukan pada 65 subjek menyatakan bahwa validitas skala pola asuh orangtua bergerak dari -0,542 sampai 0,617 terdapat 24 item yang gugur dari 60 item yang diuji,sehingga jumlah item yang valid sebanyak 36 item. Kemudian peneliti menggugurkan 24 item yang tidak valid tersebut sehingga diperoleh koefisien korelasi yang bergerak dari 0,229 hingga 0,721. Reliabilitas skala pola asuh orangtua adalah 0,886 yang berada di atas nilai maksimum 0,6 sehingga skala dapat dinyatakan reliabel (Arikunto,1993).

Uji coba yang dilakukan pada skala kemandirian menyatakan bahwa validitas aitem bergerak dari dari $-0,090$ sampai 0,532 dan terdapat 26 item yang gugur dari 60 item 
yang diuji,sehingga jumlah item yang valid sebanyak 34 item. Kemudian peneliti menggugurkan 26 item yang tidak valid tersebut sehingga diperoleh koefisien korelasi yang bergerak dari 0,220 hingga 0,659. Reliabilitas skala kemandirian adalah 0,876 yang berada di atas nilai maksimum 0,6 sehingga kuesioner dapat dinyatakan reliabel (Arikunto,1993).

\section{Metode pengumpulan data}

Dalam penelitian ini, peneliti menggunakan kuesioner dengan dua skala, yaitu skala pola asuh dan skala kemadirian. Kuesioner 1 yang berisi tentang skala pola asuh (untuk mengetahui gambaran tipe pola asuh yang diterapkan oleh orangtua subjek). Kuesioner 2 tentang kemandirian (untuk mengukur kemandirian diri responden). Kedua kuesioner tersebut, sebelumnya sudah diuji validitas dan reliabilitasnya. Skala pola asuh orangtua memiliki item yang valid sebanyak 36 item dengan nilai reliabilitas 0,886 dan skala kemandirian memiliki item yang valid sebanyak 34 item dengan nilai reliabilitas 0,876 .

\section{Teknik analisis data}

Desain yang digunakan dalam penelitian ini adalah kuantitatif komparasi menggunakan perhitungan Metode One Way Anova dengan program SPSS 16.0 for windows. Metode Anova adalah tergolong analisis komparatif lebih dari dua atau lebih dari dua rata-rata. Tujuan pada metode ini untuk membandingkan lebih dari dua rata-rata. Gunanya untuk menguji kemampuan generalisasi artinya data sampel dianggap dapat mewakili populasi (Sunarto,2009). Adapun tujuan peneliti memakai metode one way anova yaitu ingin melihat besar kontribusi independent variable (pola asuh orangtua) terhadap dependent variable (kemandirian), dan pada metode one way anova terdapat post hoc test yang berfungsi untuk mengetahui hasil perbandingan antara masing-masing tipe pola asuh orangtua terhadap kemandirian sehingga nantinya akan memperkaya data ketika membahas hasil penelitian.

\section{HASIL PENELITIAN}

Sebelum melakukan analisis one way anova, terdapat dua uji asumsi yang harus dipenuhi. Uji asumsi pertama yang harus dipenuhi adalah uji normalitas untuk melihat penyimpangan frekuensi observasi distribusi gejala yang diteliti dari frekuensi teoritik kurva normal, atau untuk mengetahui normal atau tidaknya sebaran skor variabel pola asuh dan kemandirian. Apablila signifikansi lebih besar dari 0,05 maka data dapat dikatakan memiliki distribusi yang normal (Sunarto, 2009). Uji normalitas dilakukan dengan menggunakan Kolmogorov-Smirnov pada SPSS 16.0 for windows. Hasil pengujian dapat dilihat pada tabel berikut :

Tabel 1

Hasil Uji Normalitas

\begin{tabular}{lc}
\hline & Kemandirian \\
\hline Kolmogorov-Smirnov Z & 0,891 \\
Asymp. Significant & 0,405 \\
(2-tailed) & \\
\hline
\end{tabular}

Sebaran data pada variabel kepribadian memiliki nilai signifikansi dengan probabilitas (p) sebesar 0,405 atau memiliki probabilitas diatas $0,05(\mathrm{p}>0,05)$. Hal ini menunjukkan bahwa sebaran data pada variabel kemandirian berdistribusi normal.

Uji asumsi kedua yang harus dipenuhi adalah uji homogenitas untuk mengetahui apakah sebaran data tersebut homogen atau tidak, yaitu dengan membandingkan kedua variannya. Uji homogenitas dilakukan untuk menunjukkan bahwa perbedaan yang terjadi pada uji statistik parametrik Jika hasil analisis uji homogenitas memperoleh nilai $(\mathrm{P}>0,05)$ itu menandakan ada perbedaan antara kedua variabel dan sebaran data dapat dikatakan homogen. Hasil uji homogenitas dapat dilihat pada tabel 2 .

\begin{tabular}{lcc}
\multicolumn{2}{c}{ Tabel 2 } \\
& Hasil Uji Homogenitas \\
\hline $\begin{array}{l}\text { Uji } \\
\text { Homogenitas }\end{array}$ & F & Signifikansi \\
\hline $\begin{array}{l}\text { Levene's } \\
\text { Test }\end{array}$ & 0.654 & 0.581 \\
\hline
\end{tabular}

Hasil pengujian diketahui bahwa varians pada setiap kelompok memiliki nilai homogenitas pada Levene Statistic sebesar 0,654 dengan nilai signifikansi dengan probabilitas (p) 0,581 atau memiliki probabilitas di atas 0,05 ( $\mathrm{p}>0,05)$. Mengacu kepada pedoman penentuan homogenitas, nilai probabilitas (p) 0,581 tersebut menunjukkan bahwa varians skor variabel yang diukur pada setiap kelompok yang diuji dalam penelitian ini adalah bersifat homogen. Sehingga data ini dapat dianalisis dengan menggunakan analisis parametrik ( one way anova ) dengan menggunakan alat bantu perangkat lunak SPSS 16.0. Variabel yang akan di uji adalah variabel pola asuh dengan kemandirian.

Peneliti membedakan karakteristik pada variabel pola asuh oragtua dengan menggunakan rumus kategorisasi bukanjenjang dengan jenis data nominal (Azwar, 2000). Berdasarkan rumus pengkategorian dari Azwar (2000), peneliti kemudian mengkategorikan variabel pola asuh orangtua yang akan dicantumkan dalam tabel 3 dibawah ini : 
Tabel 3

Karakteristik Tipe pola asuh Orangtua

\begin{tabular}{cccc}
\hline $\begin{array}{c}\text { Tipe pola asuh } \\
\text { orangtua }\end{array}$ & Jumlah & Persentase & Mean \\
\hline Autoritatif & 53 & $14,7 \%$ & 112,72 \\
Otoriter & 37 & $10,3 \%$ & 97,73 \\
Permisif & 56 & $15,6 \%$ & 106,68 \\
Tipe Campuran & 214 & $59,4 \%$ & 105,36 \\
Jumlah & $\mathbf{3 6 0}$ & $\mathbf{1 0 0} \%$ & $\mathbf{1 0 5 , 8 7}$ \\
\hline
\end{tabular}

Dapat dilihat pada tabel 3 bahwa gambaran tipe pola asuh orangtua berbeda-beda di tiap anak. Pada tabel ini dapat dijelaskan bahwa orangtua yang dapat dikategorisasikan tipe autoritatif sebanyak 53 orang dengan persentase 14,7\%, orangtua yang dapat dikategorikan dengan tipe otoriter sebanyak 37 orang dengan persentase $10,3 \%$, orangtua yang dapat dikategorikan dengan tipe permisif sebanyak 56 orang dengan persentase $15,6 \%$, selain ketiga kategori pola asuh tersebut, pada hasil penelitian terdapat juga kategori tipe pola asuh orangtua dengan tipe campuran sebanyak 214 orang dengan persentase $59,4 \%$. Pola asuh tipe campuran merupakan pola asuh yang tidak terklasifikasi diantara ketiga pola asuh orangtua, yaitu pola asuh yang tidak didominasi diantara ketiga kategori pola asuh yang ada atau orangtua yang mengasuh anaknya dengan ketiga tipe pola asuh tersebut. Tidak dapat dipungkiri bahwa dalam hasil penelitian terdapat orangtua siswa yang tidak mendominasi salah satu tipe pola asuh atau menggunakan tipe pola asuh ganda. Selain karakteristik diatas, peneliti juga mengkategorikan kemandirian yang peneliti dapat dan peneliti hitung dari kuesioner skala kemadirian. Kuesioner kemandirian tersebut bertujuan untuk mengetahui seberapa mandiri para siswa tersebut yang dilihat dari tipe pola asuh orangtua.

Peneliti membedakan kategori pada variabel kemandirian dengan menggunakan rumus rentangan berdasarkan standar deviasi dan mean empiris dilihat dari kurva normal (Azwar, 2000). Kategorisasi yang dilakukan oleh peneliti terbagi kedalam 3 kategori, yaitu kategori tinggi, sedang, rendah.

Berdasarkan rumus pengkategorian skor dari Azwar (2000), peneliti kemudian mengkategorikan variabel kemandirian ke dalam tiga kategori. Pengkategorian skor variabel kemandirian dan persentasenya akan dicantumkan dalam tabel dibawah ini :

Tabel 4

Kategorisasi Skor Tingkat Kemandirian

\begin{tabular}{cccc}
\hline Skor & Kategorisasi & Jumlah & Persentase \\
\hline $\mathrm{X}<77,7$ & Rendah & 20 & $5,6 \%$ \\
$77,7 \leq \mathrm{X}<126,3$ & Sedang & 333 & $92,5 \%$ \\
$126,3 \leq \mathrm{X}$ & Tinggi & 7 & $1,9 \%$ \\
\hline TOTAL & & $\mathbf{3 6 0}$ & $\mathbf{1 0 0 \%}$ \\
\hline
\end{tabular}

Pada tabel 4 diatas merupakan hasil kategorisasi skor kemandirian pada kuesioner kemandirian. Dimana terdapat 20 siswa yang memiliki kemandirian tinggi dengan persentase
$5,6 \%$. Siswa yang memiliki kemandirian sedang sebanyak 333 siswa dengan persentase $92,5 \%$. Siswa dengan kemandirian rendah terdapat 7 siswa dengan persentase 1,9\%. Dalam hal ini siswa dengan kemandirian sedang lebih banyak dibandingkan siswa dengan kemandirian rendah dan tinggi.

\begin{tabular}{|c|c|c|c|c|c|c|}
\hline \multicolumn{7}{|c|}{$\begin{array}{c}\text { Tabel } 5 \\
\text { Kategorisasi kemandirian berdasarkan tipe pola asuh }\end{array}$} \\
\hline \multirow{8}{*}{$\begin{array}{c}\text { Kategori } \\
\text { pola asuh } \\
\text { orangtua }\end{array}$} & \multirow{4}{*}{ Autoritatif } & & \multicolumn{3}{|c|}{ Kategori mandiri } & \multirow{3}{*}{$\begin{array}{c}\text { Total } \\
53\end{array}$} \\
\hline & & & rendah & sedang & tinggi & \\
\hline & & Count & 0 & 46 & 7 & \\
\hline & & $\%$ within ktpolaasuh & $.0 \%$ & $86.8 \%$ & $13.2 \%$ & $100.0 \%$ \\
\hline & Otoriter & Count & 3 & 33 & 1 & 37 \\
\hline & & $\%$ within ktpolaasuh & $8.1 \%$ & $89.2 \%$ & $2.7 \%$ & $100.0 \%$ \\
\hline & Permisif & Count & 1 & 52 & 3 & 56 \\
\hline & & $\%$ within ktpolaasulh & $1.8 \%$ & $92.9 \%$ & $5.4 \%$ & $100.0 \%$ \\
\hline
\end{tabular}

Hasil pengkategorian kemandirian tinggi, kemandirian sedang dan kemandirian rendah berdasarkan tiga tipe pola asuh dapat dilihat pada tabel 5. Dimana orangtua yang mengasuh anaknya dengan tipe autoritatif terdapat $13,2 \%$ siswa yang memiliki kemandirian tinggi, $86,8 \%$ siswa yang memiliki tingkat kemandirian sedang, dan tidak ada siswa yang mempunyai kemandirian rendah. Berbeda dengan pola asuh otoriter, pada pola asuh ini hanya memiliki $2,7 \%$ siswa dengan kemandirian tinggi, memiliki tingkat kemandirian sedang sebanyak 89,2\% siswa dan masih terdapat sebagian anaknya yang memiliki tingkat kemandirian rendah sebanyak $8,1 \%$ siswa. Selain itu orangtua yang mengasuh anaknya dengan tipe pola asuh permisif terdapat 92,9\% siswa dengan kemandirian sedang lebih banyak dibandingkan dengan pola asuh autoritatif dan pola asuh otoriter, pada pola asuh permisif ini hanya terdapat $1,8 \%$ siswa yang memiliki kemandirian rendah dan $5,4 \%$ siswa dengan kemandirian tinggi.

\begin{tabular}{|c|c|c|c|c|c|c|}
\hline & & & \multicolumn{3}{|c|}{ Kategori mandiri } & \multirow[t]{2}{*}{ Total } \\
\hline & & & rendah & sedang & tinggi & \\
\hline Kategori & Tipe & Count & 3 & 202 & 9 & 56 \\
\hline $\begin{array}{l}\text { pola asuh } \\
\text { orangtua }\end{array}$ & Campuran & $\%$ within ktpolaasuh & $1,4 \%$ & $94,4 \%$ & $4,2 \%$ & $100.0 \%$ \\
\hline
\end{tabular}

Pada tabel 6 dapat dilihat terdapat hasil penelitian gambaran pola asuh orangtua dengan pola asuh tipe campuran. Pada hasil penelitian terdapat $1,4 \%$ dengan kategori kemandirian rendah, 94,4\% dengan kategori kemandirian sedang dan terdapat $4,2 \%$ dengan kategori tinggi. Hasil ini menunjukan bahwa dengan pola asuh tipe campuran ini memiliki kategori kemandirian tinggi dan kemandirian sedang lebih banyak dibandingkan dengan tipe pola asuh autoritatif, pola asuh permisif dan pola asuh otoriter.

Orangtua yang menerapkan pola asuh autoritatif lebih baik dibandingkan dengan pola asuh otoriter, pola asuh permisif, dan pola asuh tipe campuran. Hal ini dilihat pada tabel hasil pengkategorian kemandirian pada masing-masing tipe pola asuh, bahwa orangtua yang menerapkan pola asuh 
autoritatif tidak terdapat anak dengan kategori kemandirian rendah.

\begin{tabular}{cccccc}
\multicolumn{6}{c}{$\begin{array}{c}\text { Tabel 7 } \\
\text { Uji Anova }\end{array}$} \\
\hline \multicolumn{5}{c}{ ANOVA } \\
\hline Totalkeman & Sum of Squares & Df & Mean Square & F & Sig. \\
\hline Between Groups & 5027.764 & 3 & 1675.921 & 9.998 & .000 \\
Within Groups & 59673.836 & 356 & 167.623 & & \\
\hline Total & 64701.600 & 359 & & & \\
\hline
\end{tabular}

Berdasarkan hasil analisis one way anova yang dilakukan peneliti pada tabel 7, didapatkan hasil bahwa hasil data menunjukan nilai signifikansi sebesar 0,000 dimana nilai tersebut lebih kecil dari taraf signifikansi 0,05 ( $p<0,05)$. Jadi dapat disimpulkan bahwa ada perbedaan yang signifikan antara ketiga tipe pola asuh terhadap kemandirian. Setelah memperoleh hasil nilai signifikansi perbedaan antara tipe pola asuh, maka selanjutnya di uji dengan Post Hoc dari One Way Anova.

Tabel 8.

Tabel Post Hoc Test ( One Way Anova)

\begin{tabular}{|c|c|c|c|c|c|c|}
\hline \multirow{2}{*}{$\begin{array}{c}\text { (I) } \\
\text { ktpolaasuh }\end{array}$} & \multirow{2}{*}{$\begin{array}{c}\text { (J) } \\
\text { ktpolaasuh }\end{array}$} & \multirow{2}{*}{$\begin{array}{c}\text { Mean } \\
\text { Difference } \\
\text { (I-J) }\end{array}$} & \multirow[t]{2}{*}{ Std. Error } & \multirow[t]{2}{*}{ Sig. } & \multicolumn{2}{|c|}{$95 \%$ Confidence Interva } \\
\hline & & & & & $\begin{array}{l}\text { Lower } \\
\text { Bound }\end{array}$ & $\begin{array}{l}\text { Upper } \\
\text { Bound }\end{array}$ \\
\hline Autoritatif & Otoriter & $14.987^{*}$ & 2.932 & .000 & 9.19 & 20.78 \\
\hline & Permisif & $6.038^{*}$ & 2.623 & .023 & .85 & 11.22 \\
\hline Otoriter & Autoritatif & $-14.987^{*}$ & 2.932 & .000 & -20.78 & -9.19 \\
\hline & Permisif & $-8.949^{*}$ & 2.900 & .002 & -14.68 & -3.22 \\
\hline Permisif & $\begin{array}{c}\text { Autoritatif } \\
\text { Otoriter }\end{array}$ & $\begin{array}{l}-6.038^{*} \\
8.949^{\circ} \\
\end{array}$ & $\begin{array}{l}2.623 \\
2.900 \\
\end{array}$ & $\begin{array}{l}.023 \\
.002 \\
\end{array}$ & $\begin{array}{c}-11.22 \\
3.22 \\
\end{array}$ & $\begin{array}{c}-.85 \\
14.68 \\
\end{array}$ \\
\hline
\end{tabular}

Dari tabel diatas, untuk mengetahui tipe pola asuh mana saja yang menunjukan perbedaan kemandirian dengan signifikan maka dapat dilihat dengan tanda bintang (*) yang menunjukan adanya perbedaan mean (kemandirian) yang signifikan berdasarkan tipe pola asuh orangtua dengan melihat signifikansi $<0,05$. Tabel diatas terlihat bahwa terdapat perbedaan kemandirian tipe pola asuh autoritatif dengan pola asuh otoriter, dengan signifikansi 0,000. Pada tipe pola asuh autoritatif dengan pola asuh permisif juga memiliki perbedaan kemandirian dengan nilai signifikansi 0,023. Pada tipe pola asuh permisif juga memiliki perbedaan kemandirian dengan pola asuh otoriter dengan nilai signifikansi 0,002 .

Tabel 9.

Tabel Post Hoc Test (One Way Anova)

\begin{tabular}{|c|c|c|c|c|c|c|}
\hline \multirow[b]{2}{*}{$\begin{array}{c}\text { (I) } \\
\text { ktpolaasuh }\end{array}$} & \multicolumn{3}{|c|}{ Mean } & & \multicolumn{2}{|c|}{$95 \%$ Confidence Interval } \\
\hline & $\begin{array}{c}\text { (J) } \\
\text { ktpolaasuh }\end{array}$ & $\begin{array}{l}\text { Differen } \\
\text { ce (I-J) }\end{array}$ & Std. Error & Sig. & $\begin{array}{l}\text { Lower } \\
\text { Bound }\end{array}$ & $\begin{array}{l}\text { Upper } \\
\text { Bound }\end{array}$ \\
\hline \multirow{3}{*}{$\begin{array}{c}\text { Tipe } \\
\text { Campuran }\end{array}$} & Autoritatif & $-7.352^{*}$ & 1.986 & .000 & -11.26 & -3.45 \\
\hline & Otoriter & $7.635^{*}$ & 2.305 & .001 & 3.10 & 12.17 \\
\hline & Permisif & -1.314 & 1.943 & .499 & -5.14 & 2.51 \\
\hline
\end{tabular}

(*). Menunjukan adanya perbedaan rata-rata dengan signifikan dibawah 0,05 .

Dari tabel 9 diatas, untuk mengetahui tipe pola asuh mana saja yang menunjukan perbedaan kemandirian dengan signifikan maka dapat dilihat dengan tanda bintang (*) yang menunjukan adanya perbedaan mean (kemandirian) yang signifikan berdasarkan tipe pola asuh orangtua dengan melihat signifikansi $<0,05$. Hasil penelitian terdapat pola asuh tipe campuran,dapat dilihat bahwa terdapat perbedaan kemandirian pada pola asuh tipe campuran dengan pola asuh autoritatif dengan nilai signifikan 0,000. Selain itu juga terdapat perbedaan kemandirian yang signifikan antara pola asuh tipe campuran dengan pola asuh otoriter dengan nilai signifikan 0,001. Jika dilihat pada tabel mean antara pola asuh tipe campuran dengan pola asuh permisif tidak ditandai dengan tanda bintang yang menunjukan tidak adanya perbedaan kemandirian yang signifikan antara pola asuh tipe campuran dengan pola asuh permisif dengan nilai signifikan 0,449 .

\section{PEMBAHASAN DAN KESIMPULAN}

Sebagaimana yang telah dikemukakan di atas, hasil penelitian ini menunjukkan bahwa terdapat perbedaan yang signifikan antara tingkat kemandirian yang ditinjau berdasarkan tipe pola asuh orangtua pada siswa SMP Negeri di Denpasar.

Tipe pola asuh autoritatif memiliki perbedaan kemandirian dengan tipe pola asuh otoriter dengan nilai signifikansi 0,000. Tipe pola asuh autoritatif memiliki perbedaan kemandirian dengan tipe pola asuh permisif dengan nilai signifikansi 0,023 . Tipe pola asuh otoriter memiliki perbedaan kemandirian dengan tipe pola asuh permisif dengan signifikansi 0,002. Tipe pola asuh campuran juga memiliki perbedaan kemandirian yang signifikan dengan pola asuh autoritatif, pola asuh otoriter, namun tidak memiliki perbedaan kemandirian yang signifikan dengan pola asuh permisif.

Perbedaan kemandirian berdasarkan tipe pola asuh orangtua sesuai dengan pernyataan Hurlock (1999) yang menyatakan bahwa pola asuh orangtua memegang peranan penting bagi perkembangan kemandirian. Setiap orangtua memiliki cara pengasuhan yang berbeda-beda maka dari itu akan menghasilkan kemandirian pada anak yang berbeda pula. Hasil penelitian tentang gambaran kemandirian pada siswa SMP Negeri di Denpasar mendapatkan hasil bahwa sebagian besar siswa memiliki kemandirian sedang yaitu 92,5\%, selain itu terdapat siswa dengan kemandirian rendah sebanyak 5,6\% dan kemandirian tinggi sebanyak $1,9 \%$. Hasil penelitian juga terdapat tentang karakteristik tipe pola asuh orangtua, dimana pada gambaran pola asuh orangtua yang menerapkan tipe pola asuh autoritatif sebanyak $14,7 \%$, orangtua yang menerapkan tipe pola asuh otoriter sebanyak $10,3 \%$, orangtua yang menerapkan tipe pola asuh permisif sebanyak 15,6\%. Pada hasil penelitian juga terdapat karakteristik pola asuh tipe campuran, dimana pada tipe pola asuh ini sudah dijelaskan sebelumnya bahwa pola asuh tipe campuran ini merupakan pola asuh ganda atau tidak mendominasi salah satu dari ketiga tipe pola asuh orangtua. Gambaran pola asuh orangtua yang menerapkan pola asuh tipe campuran sebanyak 59,4\%.

Gambaran pola asuh orangtua pada penelitian ini yang menerapkan tipe pola asuh autoritatif sebanyak $14,7 \%$. Pola asuh autoritatif menghasilkan anak dengan kemandirian tinggi sebanyak 13,2\%, kemandirian sedang sebanyak $86,8 \%$, 
dan pada pola asuh ini tidak memiliki anak dengan kemandirian rendah dengan persentase $0 \%$. Dilihat pada hasil penelitian bahwa dengan pola asuh autoritatif ini tidak memiliki anak dengan kemandirian rendah yang diperkuat oleh teori Baumrind (dalam Fakhriyani, 2011) menyatakan bahwa orang tua yang menerapkan pola asuh autoritatif, akan mendorong anak untuk mampu berdiri sendiri, bertanggung jawab dan yakin terhadap diri sendiri.

Gambaran pola asuh orangtua pada penelitian ini yang menerapkan tipe pola asuh otoriter sebanyak 10,3\%. Pola asuh otoriter menghasilkan anak dengan kemandirian tinggi sebanyak 2,7\%, kemandirian sedang sebanyak $89,2 \%$, dan kemandirian tinggi sebanyak $8,1 \%$. Baumrind (dalam Fakhriyani, 2011) menyatakan bahwa orangtua yang menerapkan pola asuh otoritatif akan menghasilkan anak yang kurang berinisiatif, selalu tegang, cenderung ragu, tidak mampu menyelesaikan masalah, kemampuan komunikasinya buruk serta mudah gugup.

Gambaran pola asuh orangtua pada penelitian ini yang menerapkan tipe pola asuh permisif sebanyak $15,6 \%$. Pola asuh permisif menghasilkan anak dengan kemandirian tinggi sebanyak 5,4\%, kemandirian sedang sebanyak 92,9\% dan kemandirian rendah dengan persentase $1,8 \%$. Pada pola asuh permisif jika dikaitkan dengan teori Bumrind (dalam Fakhriyani, 2011) pola asuh ini yang cenderung memberikan kebebasan pada anak akan menjadikan anak lebih agresif, suka menurutkan kata hatinya, anak-anak menjadi tidak terkendali, tidak patuh, dan tingkah laku agresif di luar lingkungan keluarga. Namun bila anak mampu menggunakan kebebasan tersebut secara bertanggung jawab, maka anak akan menjadi seorang yang mandiri, kreatif, inisiatif, dan mampu mewujudkan aktualisasinya.

Hasil penelitian ini juga mendapatkan pola asuh tipe campuran, sebelumnya telah dijelaskan pada pengkategorian pola asuh tipe campuran. Saat pengkategorian apabila pola asuh yang tidak dapat terklasifikasi salah satu tipe pola asuh, merupakan orangtua yang menerapkan pola asuh ganda atau tidak mendominasi salah satu dari ketiga tipe pola asuh orangtua. Gambaran pola asuh orangtua yang menerapkan pola asuh tipe campuran ini sebanyak 214 orang dengan persentase $59,4 \%$. Tidak dapat dipungkiri bahwa pada kenyataan yang terjadi orangtua tidak hanya menerapkan salah satu tipe pola asuh orangtua. Hal ini didukung dengan pendapat menurut Tedjasaputra (2008) bahwa ada kalanya setiap orangtua tidak mampu dalam menerapkan salah satu tipe pola asuh dengan sepenuhnya. Terutama pada saat emosi orangtua sedang tidak stabil, saat mengalami kondisi emosi negatif, orangtua cenderung bersikap lebih otoriter terhadap anak. Selain itu saat orangtua sedang merasa senang karena bisnisnya berhasil, orangtua cenderung bersikap agak permisif terhadap anaknya. Orangtua yang menerapkan pola asuh tipe campuran ini menghasilkan anak dengan kemandirian tinggi sebanyak 4,2\%, kemandirian sedang 94,4\%, dan kemandirian rendah $1,4 \%$.

Melalui uji post hoc dapat dilihat perbedaan kemandirian berdasarkan masing-masing tipe pola asuh orangtua. Terdapat perbedaan kemandirian berdasarkan tipe pola asuh autoritatif dengan tipe pola asuh otoriter, perbedaan kemandirian berdasarkan tipe pola asuh autoritatif dengan tipe pola asuh permisif, perbedaan kemandirian berdasarkan tipe pola asuh permisif dengan tipe pola asuh otoriter. Selain itu juga pada hasil penelitian pola asuh tipe campuran juga terdapat perbedaan dengan tipe pola asuh autoritatif dengan tipe pola asuh otoriter, namun pada pola asuh tipe campuran tidak terdapat perbedaan kemandirian berdasarkan tipe pola asuh permisif. Teori Hurlock (1999) yang telah dipaparkan sebelumnya bahwa pada masing-masing tipe pola asuh memiliki gaya pengasuhan yang berbeda sehingga menghasilkan kemandirian yang berbeda pada tiap-tiap anak. Secara umum, dapat disimpulkan bahwa pola asuh autoritatif masih lebih baik jika dibandingkan dengan pola asuh otoriter, pola asuh permisif, dan pola asuh tipe campuran karena pada hasil penelitian pola asuh autoritatif tidak memiliki anak dengan kemandirian rendah.

Marheni (dalam Soetjiningsih, 2004) pada usia ini merupakan masa peralihan antara masa kanak-kanak dan masa dewasa. Pada usia 12 sampai 15 tahun anak menempuh pendidikan di tingkat sekolah menengah pertama (SMP). Pada penelitian ini umur siswa berkisar antara umur 12 sampai dengan 15 tahun. Siswa berusia 12 tahun sebanyak 3,9\%, siswa yang berusia 13 tahun sebanyak $76,7 \%$ dimana pada usia ini lebih banyak dibandingkan yang lain. Sedangkan siswa dengan usia 14 tahun sebanyak 19,4\%. Marheni (dalam Soetjiningsih, 2004) masa peralihan ini merupakan masa remaja awal di mana mereka sedang mengembangkan jati diri dan melalui proses pencarian identitas diri. Masa remaja ini tidak mempunyai tempat yang jelas yaitu bahwa mereka tidak termasuk golongan anak-anak tetapi tidak juga termasuk golongan orang dewasa. Saat ini remaja akan berjuang untuk melepaskan ketergantungannya kepada orangtua dan berusaha mencapai kemandirian sehingga mereka dapat diterima dan diakui sebagai orang dewasa.

Adapun keterbatasan dalam penelitian ini antara lain dalam penelitian ini, peneliti menggunakan pengukuran berupa angket yang diisi oleh siswa SMP Negeri di Denpasar untuk mengetahui gambaran pola asuh orangtua masingmasing. Hal ini memungkinkan adanya bias atas penilaian anak terhadap orangtuanya.

Hasil analisis data menunjukkan bahwa adanya perbedaan kemandirian berdasarkan tipe pola asuh pada siswa SMP Negeri di Denpasar. Hasil data juga menunjukkan adanya perbedaan kemandirian pada masing-masing tipe pola asuh, diantaranya adanya perbedaan kemandirian berdasarkan tipe pola asuh autoritatif dengan tipe pola asuh otoriter, 
adanya perbedaan kemandirian berdasarkan tipe pola asuh autoritatif dengan tipe pola asuh permisif, adanya perbedaan kemandirian berdasarkan tipe pola asuh otoriter dengan tipe pola asuh permisif, selain itu adanya perbedaan kemandirian pada pola asuh tipe campuran terhadap pola asuh autoritatif dan pola asuh otoriter.

Tipe pola asuh autoritatif merupakan tipe pola asuh yang memiliki anak dengan kemandirian paling baik dibandingkan tipe pola asuh otoriter dan tipe pola asuh permisif maupun pola asuh tipe campuran.

Saran yang dapat peneliti berikan yaitu bagi orangtua agar lebih memperhatikan tipe pola asuh yang diterapkan pada anak didalam keluarga agar terbentuknya sikap anak yang lebih mandiri, bertanggungjawab, dan mampu dalam menyelesaikan masalah yang dihadapi. Hal tersebut dapat dilakukan dengan memanfaatkan komunikasi yang efektif antara orangtua dan anak,menciptakan suasana yang harmonis dan baik antar keluarga agar anak lebih bersikap terbuka terhadap orangtuanya. Selain itu menjadi orang tua yang memberikan kasih sayang dan pengertian terhadap anaknya, sebaiknya orang tua menjadi pendengar yang baik bagi anakanaknya. Dengam demikian anak akan merasa bahwa orangtua mampu memahami diri merekan setiap orangtua juga mencoba untuk lebih mendengarkan masalah-masalah yang dihadapi oleh anak dan memberikan solusi yang terbaik. Saran bagi remaja, diharapkan mampu dalam mengembangkan kemandirian dari dalam dirinya dan remaja yang masih memiliki kemandirian rendah diharapkan mampu dalam mengevaluasi kembali kemandirian yang dimilikinya .

Peneliti juga menyarankan agar peneliti selanjutnya bisa mempertimbangkan untuk lebih memperhatikan kajian teori tentang masing-masing tipe pola asuh, salah satu contoh terdapat pola asuh orangtua yang tidak terklasifikasi. Peneliti selanjutnya sebaiknya memperhatikan dan cermat dalam penyusunan item pada masing-masing skala agar dalam uji coba item tidak terdapat banyak item yang gugur atau sebagian besar gugur pada satu indikator. Selain itu lebih memperhatikan variabel-variabel lain yang mempengaruhi kemandirian pada anak dan juga faktor lain yang mempengaruhi pola asuh orangtua.

\section{DAFTAR PUSTAKA}

Ali, M., \& Asrori, M. (2004). Psikologi remaja perkembangan peserta didik. Jakarta: PT. Bumi Aksara.

Arikunto, S. (1993). Seri manajemen sumber daya manusia psikologi industri. Bandung: Alumni.

Azwar, S. (2000). Penyusunan skala psikologi. Yogyakarta: Pustaka Pelajar.

Baumrind, D. (1991). The influence of parenting style on adolescent competence and substance use. Journal of Early Adolescene, Vol 11 No 1: 56-95

Bisono, T. (16 Mei 2013). Gagalnya Kemandirian Remaja Sebagai Penyebab Utama Meningkatnya Penyalagunaan Narkotika,
Minuman Keras, Ekstasi Dan Obat-Obatan Terlarang. Humas BNN. Akses : 5 Juni 2013,

http://dedihumas.bnn.go.id/read/section/artikel/2013/05/16/602/gagal nya-kemandirian-remaja-sebagai-penyebab-utamameningkatnya-penyalagunaan-narkotika-minuman-kerasekstasi-dan-obat-obatan-terlarang

BP. (18 Desember 2009). Memahami penyebab anak sulit konsentrasi. Bali Post. Akses: 5 Juni2013, http://www.balipost.co.id/mediadetail.php?module=detailbe ritaminggu\&kid $=13 \& \mathrm{id}=26533$

Fakhriyani, D. (2011). Hubungan antara pola asuh orangtua dengan kecerdasan emosional siswa MI taufiqus shibyan desa tlangoh kecamatan proppo kabupaten pamekasan madura. Skripsi. Fakultas Psikologi Universitas Islam Negeri (UIN) Maulana Malik Ibrahim Malang.

Hurlock, E. A. (1999). Psikologi perkembangan: Suatu pendekatan sepanjang rentang kehidupan. Edisi Kelima. Jakarta: Penerbit Erlangga.

Imtiyas, Y. (2010). Hubungan antara pola asuh orang tua dengan kemandirian remaja. Psikologi.

Irmawati. (2002). Motivasi berprestasi dan pola pengasuhan pada suku bangsa Bangsa Batak Toba di Desa Parparean II dan suku bangsa Bangsa Melayu di Desa Bogak (Studi Etnopsikologi). (Tesis S-2). Jakarta: Fakultas Pascasarjana UI

Lie, Anita, \& \& Prasasti, S. (2004). 101 Cara membina kemandirian dan tanggung jawab anak. Jakarta: Elex Mdia Komputindo.

Marheni, A. (2004). Perkembangan psikososial dan kepribadian remaja dalam Soetjiningsih. tumbuh kembang remaja dan permasalahannya. Jakarta: CV. Sagung Seto.

Monk, F. (1999). Psikologi Perkembangan : Pengantar dalam berbagai bagiannya. Yogyakarta: Gajah Mada University Press.

Mutadin, Z. (2002). Mengenal kecerdasan emosional remaja. Retrieved Oktober 10, 2012, From Psikologi: http://www.epsikologi.com

Nurgiyantoro, B., Gunawan, \& Marzuki. (2004). Statistik terapan (untuk penelitian ilmu-ilmu sosial). Yogjakarta: Gadjah Mada University Press.

Siswoyo, Dwi dkk. (2007). Ilmu Pendidikan. Yogyakarta: UNY Press.

Soetjiningsih. (2004). Tumbuh kembang remaja dan permasalahannya. Jakartaa: Sagung Seto.

Steinberg. (2002). Adolescence: sixth edition. USA: McGraw Hill Higher Education.

Sugiyono. (2012). Metode penelitian pendidikan pendekatan kuantitatif, kualitatif dan $R \& D$. Bandung: Alfabeta.

Tedjasaputra, Mayke S. (2008). Pola asuh yang tepat. Akses : 5 Juni 2013, http://keluargasehat.wordpress.com/2008/04/10/ 